inOedia $\quad \begin{aligned} & \text { InMedia } \\ & \text { The French Journal of Media Studies }\end{aligned}$

6 | 2017

Fields of Dreams and Messages

\title{
The Art of Walt Disney Animation Studios: Movement by Nature
}

Thibaut Clément

\section{(2) OpenEdition \\ 1 Journals}

\section{Electronic version}

URL: http://journals.openedition.org/inmedia/877

DOI: $10.4000 /$ inmedia. 877

ISSN: 2259-4728

\section{Publisher}

Center for Research on the English-Speaking World (CREW)

\section{Electronic reference}

Thibaut Clément, "The Art of Walt Disney Animation Studios: Movement by Nature », InMedia [Online], 6 | 2017, Online since 18 December 2017, connection on 23 September 2020. URL : http:// journals.openedition.org/inmedia/877 ; DOI : https://doi.org/10.4000/inmedia.877

This text was automatically generated on 23 September 2020

(C) InMedia 


\title{
The Art of Walt Disney Animation Studios: Movement by Nature
}

\author{
Thibaut Clément
}

1 Created in collaboration with the Walt Disney Animation Research Library, the "The Art of Walt Disney Animation Studios: Movement by Nature" exhibition held at the Paris Musée Art Ludique holds special appeal for students of popular culture. Some of that interest will, of course, stem from the 350 pieces on display, and some from the process by which the Disney corporation further "artifies" ${ }^{1}$ popular media, providing the studio's products with an additional layer of cultural legitimacy and allowing the studio to present itself as a purveyor of fine arts in the process. ${ }^{2}$

2 The exhibition is composed of six major sections arranged in chronological order. Entitled "Nascent Art," the first section devotes itself entirely to Disney's early animated shorts, from 1918 to 1939, with exclusive emphasis on the studio's roster of beloved characters - starting, unsurprisingly, with Mickey Mouse's first appearances in Plane Crazy and Steamboat Willy, here presented by means of Ub Iwerk's strikingly sparse and energetic animation drawings and storyboards. Conspicuously absent from the selected artworks are the Silly Symphonies - including Oscar winning efforts such as The Old Mill (1938) - here entirely left out in favor of such crowd-pleasing figures as Mickey Mouse, Donald Duck or Goofy. Entitled "First Feature films", the exhibition's second part focuses on artworks produced for Snow White (1937), Pinocchio (1940), and Fantasia (1940). Bearing the title of "Life as Inspiration," the exhibition's third part devotes itself to wartime films such as Bambi (1942) and Saludos Amigos (1942) and might come closest to fulfilling the exhibition's avowed purpose, namely exploring Disney's quest for realism through the close, quasi-scientific observation of nature - as notably documented here by animator Rico Lebrun's Animal Studies for Bambi. In its fourth part, the exhibition explores the so-called "Modern turn of the Fifties," with artworks from Alice in Wonderland (1951), Lady and the Tramp (1955), Sleeping Beauty (1959), and 101 Dalmatians (1961). Rich in concept artworks departing - sometimes spectacularly - from the round, cuddly drawing style most readily associated with Disney animation, the section's highlights include a spectacular story-sketch for 101 Dalmatians' car chase 
scene - a vivid testimony to the iterative, collaborative and almost exclusively visual process of story development typical of the Disney studio. Sadly, though, this aspect is barely touched upon in the sketch's presentation. In its fifth part, "The New Artistic Dimension of the 1980s," the exhibition focuses on films closely associated with the socalled Disney Renaissance initiated with the company's new management, with emphasis laid on The Little Mermaid (1989), Beauty and the Beast (1991), The Lion King (1994), Pocahontas (1995), and Mulan (1998). Oddly enough, the critically acclaimed and third highest grossing traditionally animated film Aladdin is entirely omitted from this section. In its sixth and final section, "Exploring Modern Mythology", the exhibition turns to more recent digitally animated features and, accordingly, presents digital art for Tangled (2010), Wreck it Ralph (2012), Big Hero 6 (2014), Frozen (2013), and Zootopia (2016). One notable exception, Moana (2017), while a digitally animated film, is here presented by means of hand-drawn concept art - most likely the influence of its directors John Musker and Ron Clements, themselves traditional animation veterans. More generally, while Disney's digital turn has opened new esthetic avenues for the animation studio's artists, some of the works in this final section showed inventive use of new technologies for exploring older styles, as evidenced by Dan Cooper's preRaphaelite inspirations for Tangled's concept art.

3 Chief among the exhibition's highlights is the great diversity of drawings on display, with the author identifying at least five types of artworks, including animation drawings, story-sketches, concept art, background paintings as well as layout drawings. Also apparent from the art selection is the highly collaborative nature of the process of movie-making, as made clear in the concept artworks, whose visual styles are much more diverse than appear in the studio's finished products. In that respect, artists involved in the development phase display surprisingly daring and innovative styles, testifying to both new developments in the art world and acute knowledge of art history. This is most apparent in Mary Blair's naïve, folk-inspired art for Alice in Wonderland, Eyvind Earle's exquisitely detailed take on medieval illumination for Sleeping Beauty, or Walt Peregoy's delicate line drawings superimposed over bold color blocks - a style initially developed for 101 Dalmatians and the film's rough outlines resulting from the Xerox process. Finally, the animation drawings are obviously the work of accomplished artists, if any confirmation was ever needed: especially striking in that respect are the expressive strokes of Keane's drawings for Beast's transformation, or in the raw energy and simplicity of Ub Iwerk's original drawings for Mickey Mouse's first shorts

4 Yet the exhibition is not without its flaws - some of them inherent to exhibitions on film-making, where, too often, individual artifacts are isolated from their original medium (i.e. film) and recategorized as artworks in their own right, whose function and value is transformed from primarily utilitarian or instrumental to purely esthetic. To this extent, the further "artification" of individual drawings from the Disney archives rests, in part, on their decontextualization. As a result, the very nature of the drawings and paintings on display, and how their intended uses accounts for their style or medium, remain largely unexplained, with the viewer left to figure out who the artists are and what their roles and contributions within the animation department might have been. Little is also said of how the economics of movie-making affects the films' esthetics: the impact of Technicolor on the films' color palette is not discussed, while the effect of the Xerox process on the animation and visual style of the studio's 1960s production remains virtually unexplored. ${ }^{3}$ Likewise, few if any references are made to 
the studio as a business organization - much less to its history and economic and management vagaries. As a result, the motivations for the selection of the works on display remain unclear, with no reference to Disney's pre-Mickey Mouse productions nor any explanation for the twenty-odd year gap between sections four and five - when much of the studio's production in the late 1960s and 1970s suffered from lack of guidance, poor management and sometimes disappointing box office returns as a result of Walt and Roy Disney's passing in 1966 and 1971. More disappointingly, and despite the exhibition title's claims to the contrary, not much is really made of Disney's unique animation style, aside from the studio's claims to realism in section three. With the occasional exceptions of a few storyboards, most drawings are not shown as part of sequences but only presented as individual "stills." While it certainly helps emphasize the artistry of the animators behind them, this slightly obscures their meaning and role within the context of the original films.

5 Some such limits likely result from the exhibition producers' necessary cooperation with the Disney corporation, for whom the exhibition represents not only another avenue for the commercial exploitation of existing material, but also a prestigious publicity event - hence the heavy emphasis on all of the studio's latest releases, from Tangled to Moana, whose commercial appeal remains widest. Still, the exhibition represents a welcome and all-too-rare opportunity to take a first-hand look at the striking art produced behind the scenes. And while the selection of artworks seems largely informed by imperatives of commercial appeal (with only the studio's biggest hits and public favorites represented), the exhibitions does offer fascinating insight into the film development process as well as the variety of artists who called the studio their home and found surprisingly open avenues for individual expression and personal styles.

Paris Musée Art Ludique

October 14, 2016 - March 5, 2017

References:

Shapiro, Roberta and Nathalie Heinich. "When is Artification?" Contemporary Aesthetics Special Volume, 4 (2012).

\section{ENDNOTES}

1. Roberta Shapiro and Nathalie Heinich define artification as the process by which "things [...] come to be seen as works of art." Shapiro and Heinich, "When Is Artification?"

2. This strategy has been pursued for some decades now, with "Art of Disney" galleries in various theme parks offering Disney-themed paintings and sculptures - or, probably even more significantly, with the corporation's helping hand in the organization of the 2006 Grand Palais exhibition Il était une fois Walt Disney - Aux sources de l'art des studios Disney. 
3. It is only briefly mentioned in one of the occasional museum labels referencing actual production processes, along with four other such signs on the multiplane camera, the so-called "Nine old men," Cruella's car model, and Maleficent's transformation

\section{AUTHOR}

THIBAUT CLÉMENT

Thibaut Clément is Associate Professor in American Studies at the Université Paris-Sorbonne. 